\title{
Drying and characterization of myrtle pulp
}

\author{
Regilane M. Feitosa ${ }^{1}$, Rossana M. F. de Figueirêdo ${ }^{2}$, Alexandre J. de M. Queiroz ${ }^{2}$, \\ Flávia C. dos S. Lima ${ }^{3} \&$ Emanuel N. A. de Oliveira ${ }^{4}$ \\ ${ }^{1}$ Universidade Federal de Campina Grande/Centro de Ciências e Tecnologia/Pós-doutorado em Engenharia de Processos. Campina Grande, PB. E-mail: \\ regilanemarques@yahoo.com.br \\ ${ }^{2}$ Universidade Federal de Campina Grande/Centro de Tecnologia e Recursos Naturais/Unidade Acadêmica de Engenharia Agrícola. Campina Grande, \\ PB. E-mail: rossana@deag.ufcg.edu.br; alex@deag.ufcg.edu.br (Corresponding author) \\ ${ }^{3}$ Instituto Federal de Educação, Ciência e Tecnologia do Pernambuco. Belo Jardim, PE. E-mail: flavia.c.7@hotmail.com \\ ${ }^{4}$ Instituto Federal de Educação, Ciência e Tecnologia do Rio Grande do Norte. Pau dos Ferros, RN. E-mail: emanuel.oliveira16@gmail.com
}

\section{Key words:}

Eugenia gracillima

additives

mathematical models

foam mat

\begin{abstract}
A B S T R A C T
The objective of this study was to develop formulations of myrtle pulp with emulsifier/ stabilizer (Emustab ${ }^{\circledR}$ and Super Liga Neutra ${ }^{\circledR}$ ) in different proportions; characterize the best foam, based on density and over-run; and determine drying kinetics at temperatures of $50,60,70,80$ and $90^{\circ} \mathrm{C}$ and thicknesses of $0.5,1.0$ and $1.5 \mathrm{~cm}$. Incorporation of $1.5 \%$ Emustab $^{\circledR}$ and $0.5 \%$ Super Liga Neutra ${ }^{\circledR}$ to the myrtle pulp (F1) proved to be effective for foam-mat drying. The addition of additives influenced the physicochemical parameters of the whole myrtle pulp. The Midilli et al. model showed the best fit to the experimental data.
\end{abstract}

\section{Secagem e caracterização da polpa de murta}

\section{Palavras-chave:}

Eugenia gracillima

aditivos

modelos matemáticos

camada de espuma

\section{R E S U M O}

Neste trabalho objetivou-se desenvolver formulações de polpa de murta adicionada de emulsificante/estabilizante (Emustab ${ }^{\circledR}$ e Super Liga Neutra ${ }^{\circledR}$ ) em proporções diferentes; caracterizar a melhor espuma, com base na densidade e over-run; e determinar as cinéticas de secagem nas temperaturas de 50,60, 70, 80 e $90^{\circ} \mathrm{C}$ e nas espessuras 0,5, 1,0 e 1,5 cm. A incorporação de $1,5 \%$ de Emustab ${ }^{\circledR}$ e $0,5 \%$ Super liga Neutra ${ }^{\circledR}$ à polpa de murta $(F 1)$ mostrou-se eficaz para a secagem em camada de espuma. A adição de aditivos influenciou nos parâmetros físico-químicos da polpa de murta integral. O modelo de Midilli et al. se destacou como o melhor ajuste aos dados experimentais. 


\section{INTRODUCTION}

Myrtle is an underexploited fruit that has aroused interest of consumers because of its nutritional, functional and sensory properties. With fast deterioration, it requires the application of technological treatments to preserve its nutritional quality and prolong its useful life, in order to enable its commercialization. The traditional process to achieve such goal is the reduction of moisture content through drying. However, fruit pulp drying usually involves expensive processes, such as spray-drying and lyophilization. In conventional dryers, the drying process faces technological problems related to the high contents of sugars, which promote caramelization and excessive loss of sensory characteristics. One method used to overcome this problem is foam-mat drying, which has low cost of operation and implementation, but requires the utilization of foaming additives, whose effectiveness will lead to successful drying and obtainment or acceptable maintenance of nutritional and sensory characteristics (Widyastutil \& Srianta, 2011; Kadam \& Balasubramanian, 2011). The drying process through this method needs to be monitored by determinations of quality of the obtained product, to allow measurable recommendations of its applicability.

This process can be used in large-scale production of fruit pulp powders, due to its adequacy to various types of fruits, good retention of nutritional quality, easy reproduction and low cost. Fruit powders obtained through this process have high economic potential compared with their liquid equivalents, such as reduced volume or weight, reduced storage space, simpler handling and transport and longer shelf life. They can also be used in juices, yogurts, beverages, ice creams and jellies (Sangamithra et al., 2015).

Given the above and as a way to assess the application of this drying method, this study aimed to evaluate different formulations elaborated with myrtle pulp and additives, select the best foam and determine foam-mat drying kinetics at temperatures from 50 to $90{ }^{\circ} \mathrm{C}$ and thicknesses of $0.5,1.0$ and $1.5 \mathrm{~cm}$.

\section{Material ANd Methods}

The raw materials used in the study were ripe myrtles (Eugenia gracillima Kiaersk) from the Araripe Plateau, municipality of Exu, PE. Fruits were manually selected, washed, sanitized (50-ppm sodium hypochlorite), rinsed and depulped using a mechanical depulper, obtaining whole pulp, which was packed in low-density polyethylene bags and stored in a freezer at $-22^{\circ} \mathrm{C}$.

Preliminary tests were conducted to define the additives to be used and their range of concentrations. After the tests, three formulations were prepared with myrtle pulp and different concentrations of the additives Emustab ${ }^{\circledast}(\mathrm{E})$ and Super Liga Neutra ${ }^{\circledR}($ SLN), purchased in the market of Campina Grande, PB: Formulation F1 - pulp + 1.5\% E + 0.5\% SLN; Formulation F2 - pulp $+1.0 \%$ E + 0.5\% SLN; Formulation F3 - pulp + $1.0 \% \mathrm{E}+1.0 \% \mathrm{SLN}$. The formulations were beaten in electric beater to form the foams, which were evaluated for density (determined in $100-\mathrm{mL}$ aluminum pycnometer) and over- run (Eq. 1), during the different beating times $(5,10,15$ and $20 \mathrm{~min}$ ). These data were used to select the formulation F1 for the evaluation of chemical and physical parameters and determination of drying kinetics.

$$
\text { Over-run }=\frac{\rho_{\rho}-\rho_{\mathrm{f}}}{\rho_{\mathrm{f}}} \times 100
$$

where:

over-run - (\%);

$\rho_{\rho} \quad$ - pulp density, $\mathrm{g} \mathrm{cm}^{-3}$; and,

$\rho_{\mathrm{f}} \quad$ - foam density, $\mathrm{g} \mathrm{cm}^{-3}$.

Whole pulp and the Formulation F1 were analyzed for chemical and physical parameters: total soluble solids, moisture content, total titratable acidity and ashes, according to AOAC (2007); pH, total anthocyanins (Francis, 1982); total sugars, glucose, xylose and sucrose through high-efficiency liquid chromatography, according to the methodology NREL LAP014 (2008); water activity at $25^{\circ} \mathrm{C}$ (Aqualab CX-2T - Decagon); and color in a spectrophotometer (Mini Scan Hunter Lab), reading the values of $\mathrm{L}^{*}$ (luminosity), $+\mathrm{a}^{*}$ (redness) and $+\mathrm{b}^{*}$ (yellowness). The selected foam (F1) was also evaluated for color degradation under room conditions $\left(25^{\circ} \mathrm{C}\right)$, during 60 min, determining $L^{*},+a^{*},+b^{*}$ and the total color difference $\left(\Delta \mathrm{E}^{\star}\right)$ using Eq. 2 .

$$
\Delta \mathrm{E}^{*}=\left[\left(\Delta \mathrm{L}^{*}\right)^{2}+\left(\Delta \mathrm{a}^{*}\right)^{2}+\left(\Delta \mathrm{b}^{*}\right)^{2}\right]^{\frac{1}{2}}
$$

where:

$\Delta \mathrm{E}^{\star}$ - total color difference;

$\Delta \mathrm{L}^{*}$ - luminosity difference between whole pulp and powder sample;

$\Delta \mathrm{a}^{*}$ - redness difference between the pulp and powder sample; and,

$\Delta \mathrm{b}^{*}$ - yellowness difference between the pulp and powder sample.

The experimental data were analyzed using the software ASSISTAT, Beta version 7.7 (Silva \& Azevedo, 2016). For foam density and over-run data, a completely randomized design was used in $3 \times 4$ factorial scheme (proportions of additives $\mathrm{x}$ beating times), with 3 replicates. For the characterization and color degradation evaluation of F1, a completely randomized design was applied and the means were compared by Tukey test at 0.05 probability level.

The F1 foam for a 10-min beating time was spread on trays with thicknesses of $0.5,1.0$ and $1.5 \mathrm{~cm}$ and dried in forcedair oven at temperatures of 50, 60, 70, 80 and $90^{\circ} \mathrm{C}$. Drying kinetics was determined by weighing the trays until constant weight, and moisture content was calculated through Eq. 3.

$$
R X=\frac{X-X_{e}}{X_{i}-X_{e}}
$$

where:

RX - moisture ratio of the product, dimensionless; 
X - moisture content of the product at a certain time, dry basis;

$\mathrm{X}_{\mathrm{i}} \quad$ - initial moisture content of the product, dry basis; and

$\mathrm{X}_{\mathrm{e}}$ - equilibrium moisture content of the product, dry basis.

The models Page (Eq. 4), Exponential (Eq. 5) and Midilli et al. (2002) (Eq. 6) were fitted to the drying kinetic curves through nonlinear regression, using the program Statistica $7.0^{\circledR}$.

$$
\begin{gathered}
\mathrm{MR}=\exp \left(-\mathrm{kt}^{\mathrm{n}}\right) \\
\mathrm{MR}=\mathrm{a} \exp (-\mathrm{kt})+\mathrm{c} \\
\mathrm{MR}=\mathrm{a} \cdot \exp \left(-\mathrm{kt}^{\mathrm{n}}\right)+\mathrm{bt}
\end{gathered}
$$

where:

MR - moisture ratio, dimensionless;

$\mathrm{k}, \mathrm{n}, \mathrm{a}, \mathrm{b}, \mathrm{c}$ - constants of the model; and,

$\mathrm{t} \quad$ - time, $\min$.

The model with the best fit was selected based on coefficient of determination $\left(\mathrm{R}^{2}\right)$, mean square deviation (Eq. 7) and residual distribution $(\mathrm{RD})$.

$$
\operatorname{MSD}=\sqrt{\frac{\sum\left(\mathrm{RX}_{\text {pred }} \mathrm{RX}_{\text {exp }}\right)^{2}}{\mathrm{n}}}
$$

where:

MSD - mean square deviation;

$\mathrm{RX}_{\text {pred }}$ - moisture ratio predicted by the model;

$\mathrm{RX}_{\text {exp }}^{\text {pred }}$ - experimental moisture ratio; and,

n - number of observations.

\section{Results AND Discussion}

Foam density and over-run are parameters that determine the best formulation to be dehydrated and obtain the best powder, in terms of quality. Table 1 shows the mean values of foam density and over-run as a function of the different formulations and beating times. Density values of the foams of the different formulations significantly decreased as the beating time increased and, among the studied formulations, the increase of Super Liga Neutra ${ }^{\circledR}$ influenced the increase of density $(\mathrm{p}<0.05)$. Density values of the formulations were below the range reported by Soares et al. (2001), who considered values between 0.1 and $0.6 \mathrm{~g} \mathrm{~cm}^{-3}$ as ideal for foam-mat drying.

Thuwapanichayanan et al. (2012), evaluating banana pulp foam-mat drying with densities of $0.3,0.5$ and $0.7 \mathrm{~g} \mathrm{~cm}^{-3}$, observed that at the lowest density the banana pulp dried with higher efficiency and speed, which facilitated water movement from the inside to the surface of the sample, playing a fundamental role in the determination of drying kinetics and texture of the product.

Over-run significantly increased with the increment in beating time and the greater expansion occurred at the time of $20 \mathrm{~min}$ for all samples. The largest volumetric expansion was observed in F1, which contained greater quantity of Emustab ${ }^{\circledR}$. F1 was selected for the experiments because it has lowest density and highest over-run.

Figure 1 represents F1 with the values of foam density and overrun for the different beating times. The cross between the curves of density and over-run indicates the best beating time (Karim \& Wai, 1999). Therefore, based on this analysis, the time of $10 \mathrm{~min}$ was considered as ideal for foam beating. Beating time affects the content of volatile compounds and, the longer the beating time, the greater the losses of these compounds (Thuwapanichayanan et al., 2012). Prolonged beating time can be excessive, leading to collapse of foam structure (Raharitsifa et al., 2006).

Table 2 shows the mean values and standard deviations of the characterization of whole myrtle pulp and the selected foam (F1). Comparing the foam and whole pulp, there is a reduction of $\mathrm{pH}$, which makes the foam more acid. Contrarily, Souza et al. (2011), evaluating the effect of addition of Emustab on 'cupuaçu' pulp, found a trend of increase in $\mathrm{pH}$, compared with the whole pulp.

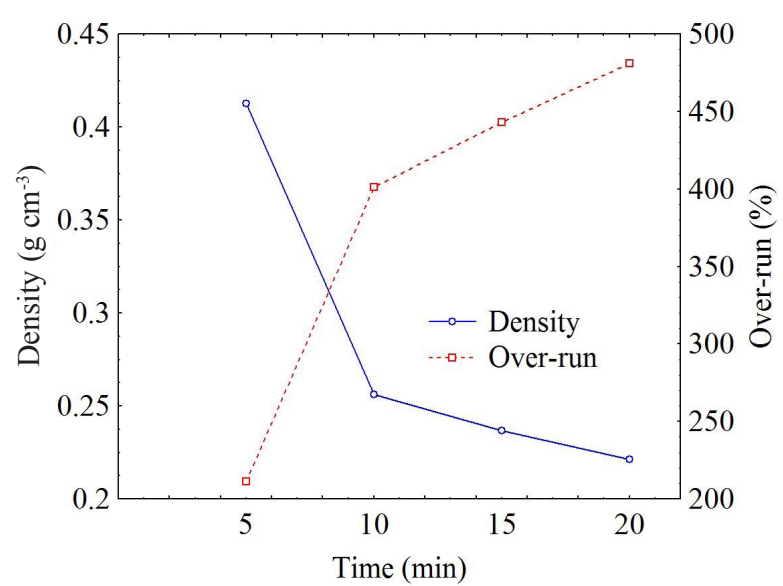

Figure 1. Mean values of foam density and over-run as a function of the beating time for the Formulation F1 (pulp

\begin{tabular}{|c|c|c|c|c|c|c|}
\hline \multirow{3}{*}{$\begin{array}{l}\text { Beating time } \\
\quad(\mathrm{min})\end{array}$} & \multicolumn{6}{|c|}{ Formulations } \\
\hline & \multicolumn{3}{|c|}{ Density $\left(\mathrm{g} \mathrm{cm}^{-3}\right)$} & \multicolumn{3}{|c|}{ Over-run (\%) } \\
\hline & F1 & F2 & F3 & F1 & F2 & F3 \\
\hline 5 & $0.4163 \mathrm{aC}$ & $0.4569 \mathrm{aB}$ & $0.4738 \mathrm{aA}$ & $208.67 \mathrm{dA}$ & $181.24 \mathrm{~dB}$ & $171.21 \mathrm{dC}$ \\
\hline 10 & $0.3200 \mathrm{bC}$ & $0.3433 \mathrm{bB}$ & $0.4198 \mathrm{bA}$ & $301.56 \mathrm{cA}$ & $274.30 \mathrm{cB}$ & $206.09 \mathrm{cC}$ \\
\hline 15 & $0.2405 \mathrm{cC}$ & $0.2716 \mathrm{cB}$ & $0.3718 \mathrm{cA}$ & $434.30 \mathrm{bA}$ & $373.12 \mathrm{bB}$ & $245.61 \mathrm{bC}$ \\
\hline 20 & $0.2246 \mathrm{dC}$ & $0.2543 \mathrm{~dB}$ & $0.3779 \mathrm{cA}$ & $472.12 \mathrm{aA}$ & $405.30 \mathrm{aB}$ & $240.03 \mathrm{aC}$ \\
\hline
\end{tabular}
$+1.5 \%$ Emustab $^{\circledR}+0.5 \%$ Super Liga Neutra ${ }^{\circledR}$ )

Table 1. Mean values of foam density and over-run for the different formulations (LF), as a function of different beating times

Means followed by the same letters, lowercase in columns and uppercase in rows, do not differ statistically by Tukey test at 0.05 probability level

Formulation F1 - pulp $+1.5 \% \mathrm{E}+0.5 \%$ SLN; Formulation F2 - pulp + 1.0\% $\mathrm{E}+0.5 \%$ SLN; Formulation F3 - pulp $+1.0 \% \mathrm{E}+1.0 \%$ SLN 
Table 2. Mean values and standard deviations of the parameters evaluated in the whole pulp and in the Formulation F1

\begin{tabular}{lcc}
\hline \multicolumn{1}{c}{ Parameter } & Whole pulp & Formulation F1 \\
pH & $3.33 \pm 0.00$ & $3.27 \pm 0.00$ \\
Total soluble solids ( ${ }^{\circ}$ Brix) & $12.30 \pm 0.00 \mathrm{~b}$ & $15.50 \pm 0.00 \mathrm{a}$ \\
Moisture content (\% w.b.) & $81.26 \pm 0.25 \mathrm{a}$ & $80.44 \pm 0.42 \mathrm{~b}$ \\
Total solids (\%) & $18.74 \pm 0.25 \mathrm{~b}$ & $19.56 \pm 0.42 \mathrm{a}$ \\
Total titratable acidity (\% citric acid) & $1.54 \pm 0.01 \mathrm{a}$ & $1.47 \pm 0.00 \mathrm{~b}$ \\
Ashes $(\%)$ & $0.85 \pm 0.01 \mathrm{a}$ & $0.60 \pm 0.01 \mathrm{~b}$ \\
Anthocyanins (mg $\left.100 \mathrm{~g}^{-1}\right)$ & $44.49 \pm 0.04 \mathrm{a}$ & $31.15 \pm 0.05 \mathrm{~b}$ \\
Density $\left(\mathrm{g} \mathrm{cm}^{-3}\right)$ & $1.285 \pm 0.021 \mathrm{a}$ & $0.320 \pm 0.01 \mathrm{~b}$ \\
Luminosity $\left(\mathrm{L}^{*}\right)$ & $14.22 \pm 0.02 \mathrm{~b}$ & $24.30 \pm 0.34 \mathrm{a}$ \\
Redness $\left(+\mathrm{a}^{*}\right)$ & $2.40 \pm 0.09 \mathrm{~b}$ & $14.41 \pm 0.25 \mathrm{a}$ \\
Yellowness $\left(+\mathrm{b}^{\star}\right)$ & $0.37 \pm 0.12 \mathrm{~b}$ & $3.86 \pm 0.52 \mathrm{a}$ \\
Water activity $\left(\mathrm{a}_{\mathrm{w}}\right)$ & $0.983 \pm 0.000 \mathrm{a}$ & $0.976 \pm 0.000 \mathrm{~b}$ \\
Total sugars $\left(\mathrm{g} \mathrm{L}^{-1}\right)$ & $130.26 \pm 30.19 \mathrm{~b}$ & $234.41 \pm 59.63 \mathrm{a}$ \\
Sucrose $\left(\mathrm{g} \mathrm{L}^{-1}\right)$ & $10.59 \pm 3.87 \mathrm{a}$ & $11.76 \pm 3.24 \mathrm{a}$ \\
Glucose $\left(\mathrm{g} \mathrm{L}^{-1}\right)$ & $34.87 \pm 3.63 \mathrm{~b}$ & $56.89 \pm 7.15 \mathrm{a}$ \\
Xylose $\left(\mathrm{g} \mathrm{L}^{-1}\right)$ & $84.80 \pm 22.68 \mathrm{~b}$ & $165.76 \pm 34.14 \mathrm{a}$ \\
\hline
\end{tabular}

Means followed by the same letter in rows do not differ statistically by Tukey test at 0.05 probability level. F1 - pulp $+1.5 \%$ Emustab $^{\circledast}+0.5 \%$ Super Liga Neutra ${ }^{\circledR}$

The content of total soluble solids (TSS) in F1 was $26.01 \%$ higher than that in the whole myrtle pulp. Soares (2009) also noted that the addition of additives (albumin, SLN and maltodextrin) in 'araçá-boi' (Eugenia stipitata Mc Vaugh) pulp promoted increase in the TSS of the formulation and that such increase led to sensory and nutritional alterations in the product.

Significant reduction of moisture content was observed with the incorporation of the additives to myrtle pulp and, consequently, increase in total solids (TS). Similar behavior was found by Feitosa et al. (2016), who added maltodextrin at different concentrations $(20,25$ and $30 \%)$ to myrtle pulp and observed that it significantly reduces moisture content and increases contents of solids in the formulations. The reduction in the total solids of a food reduces foam stability (Falade et al., 2003), indicating that TS influences stability.

Total titratable acidity (TTA) in F1 was $4.55 \%$ lower than that in whole myrtle pulp. Kadam \& Balasubramanian (2011) also observed a reduction of acidity with addition of albumin as foaming agent in tomato.

It was observed that F1 density was lower than that of whole pulp. During the beating of a liquid with foaming agents, air is transferred to the liquid forming air bubbles, which reduce foam density (Barreto, 2011). Similar behavior was reported by Chaves et al. (2013), who added albumin, Emustab ${ }^{\circledR}$ and Super Liga Neutra ${ }^{\circledR}$ to Brazilian cherry (Eugenia uniflora, L.) pulp and also observed density reduction.

Anthocyanins decreased with the formation of foam, which is due to the incorporation of additives and exposure to light during beating. For being highly unstable pigments, they can be degraded under the action of oxygen, temperature and $\mathrm{pH}$, or destroyed during processing and storage (Oliveira et al., 2013).

$\mathrm{L}^{*},+\mathrm{a}^{*}$ and $+\mathrm{b}^{*}$ values increased with the incorporation of additives. During foam preparation, there is a reduction of density and increase of volume, trapping air in liquid micelles, and such expansion can be one of the causes for the increase of $\mathrm{L}^{*}$ in the foams (Barreto, 2011).

Water activity $\left(\mathrm{a}_{\mathrm{w}}\right)$ significantly decreased with the addition of additives, which may be attributed to the solids added to the formulation. Similar behavior was found by Chaves et al. (2013), who compared the $\mathrm{a}_{\mathrm{w}}$ of Brazilian cherry pulp with that of formulations with various additives and claimed that the $\mathrm{a}_{\mathrm{w}}$ of the foam may help to select the foaming agent, because the reduction in $\mathrm{a}_{\mathrm{w}}$ decreases the drying time.

Total sugars, glucose and xylose increased with the addition of additives. According to Kadam et al. (2012), foaming agents contribute to the increase of sugars in foam-mat dried tomato powder.

Table 3 shows mean values and standard deviations of the foam color degradation for $F 1$, through the parameters $L^{*},+a^{*}$, $+\mathrm{b}^{\star}$ and total color difference $\left(\Delta \mathrm{E}^{\star}\right)$, during $60 \mathrm{~min}$. $\mathrm{L}^{*}$ and $+\mathrm{a}^{\star}$ values tended to decrease as the exposure time of the foam increased under ambient conditions, indicating that the foam became darker. Decrement in $\mathrm{L}^{*}$ indicates darkening, which can be related to the non-enzymatic darkening that occurs in the presence of sugars (Sousa et al., 2003). Foods containing anthocyanins during the processing are susceptible to changes in color, resulting from the combined effects of anthocyanin degradation and formation of dark pigments (Skrede et al., 1992).

$\Delta \mathrm{E}^{\star}$ increased with the time of exposure to the environment, showing values lower than 1.5 until $30 \mathrm{~min}$. The lower the $\Delta \mathrm{E}^{\star}$, the better, because it demonstrates that the pigment maintained the color closer to the initial one. If $\Delta \mathrm{E}^{*}$ is between 0 and 1.5 , the sample is considered to be identical to the original,

Table 3. Mean values and standard deviation of luminosity $\left(\mathrm{L}^{*}\right)$, redness $\left(+\mathrm{a}^{*}\right)$, yellowness $\left(+\mathrm{b}^{*}\right)$ and total color difference $\left(\Delta \mathrm{E}^{*}\right)$ of the foam of the Formulation $\mathrm{F} 1$, as a function of time

\begin{tabular}{|c|c|c|c|c|}
\hline \multirow{2}{*}{ Time (min) } & \multicolumn{4}{|c|}{ Parameters } \\
\hline & $\bar{L}$ & $+a^{*}$ & $+b^{*}$ & $\Delta \mathrm{E}^{*}$ \\
\hline 0 & $24.30 \pm 0.34 a$ & $14.41 \pm 0.25 a$ & $3.86 \pm 0.35 a$ & - \\
\hline 5 & $24.28 \pm 0.37 a$ & $14.21 \pm 1.77 a b$ & $3.83 \pm 5.83 a$ & $0.31 \pm 0.11 \mathrm{~h}$ \\
\hline 10 & $24.03 \pm 0.04 a b$ & $14.06 \pm 0.03 \mathrm{abc}$ & $3.99 \pm 0.09 a$ & $0.69 \pm 0.09 \mathrm{gh}$ \\
\hline 15 & $23.65 \pm 0.11 b c$ & $13.97 \pm 0.08 \mathrm{bcd}$ & $4.03 \pm 0.38 a$ & $1.11 \pm 0.24 \mathrm{fg}$ \\
\hline 20 & $23.61 \pm 0.17 b c$ & $13.77 \pm 0.15 \mathrm{cde}$ & $3.79 \pm 0.21 \mathrm{a}$ & $1.08 \pm 0.23 \mathrm{fg}$ \\
\hline 25 & $23.60 \pm 0.12 \mathrm{bcd}$ & $13.64 \pm 0.25 \mathrm{cde}$ & $3.77 \pm 0.30 a$ & $1.30 \pm 0.04$ ef \\
\hline 30 & $23.18 \pm 0.07 \mathrm{cde}$ & $13.59 \pm 0.01 \mathrm{de}$ & $3.66 \pm 0.06 a$ & $1.46 \pm 0.20$ def \\
\hline 35 & $23.10 \pm 0.04 \mathrm{de}$ & $13.47 \pm 0.07$ ef & $3.66 \pm 0.09 a$ & $1.65 \pm 0.27 \mathrm{cde}$ \\
\hline 40 & $22.93 \pm 0.05 \mathrm{e}$ & $13.37 \pm 0.02$ ef & $3.51 \pm 0.12 \mathrm{a}$ & $1.80 \pm 0.20 \mathrm{bcde}$ \\
\hline 45 & $22.89 \pm 0.06 \mathrm{e}$ & $13.13 \pm 0.10 \mathrm{fg}$ & $3.68 \pm 0.11 \mathrm{a}$ & $1.98 \pm 0.15 \mathrm{abcd}$ \\
\hline 50 & $22.82 \pm 0.03 \mathrm{e}$ & $12.94 \pm 0.05 \mathrm{gh}$ & $3.68 \pm 0.10 a$ & $2.16 \pm 0.16 a b c$ \\
\hline 55 & $22.77 \pm 0.14 \mathrm{e}$ & $12.84 \pm 0.11 \mathrm{gh}$ & $3.68 \pm 0.10 a$ & $2.27 \pm 0.14 \mathrm{ab}$ \\
\hline 60 & $22.76 \pm 0.03 \mathrm{e}$ & $12.66 \pm 0.05 \mathrm{~h}$ & $3.68 \pm 0.06 \mathrm{a}$ & $2.39 \pm 0.15 a$ \\
\hline
\end{tabular}

Means followed by the same letter do not differ statistically by Tukey test at 0.05 probability level. F1 - pulp $+1.5 \%$ Emustab $^{\circledR}+0.5 \%$ Super Liga Neutra ${ }^{\circledR}$ 
through visual observation. When $\Delta \mathrm{E}^{\star}$ is between 1.5 and 5 , the difference between colors is already noticeable; and for values higher than 5, the difference is evident (Obón et al., 2009).

Table 4 shows the parameters of the models fitted to the F1 drying kinetics at temperatures of 50, 60, 70, 80 and $90{ }^{\circ} \mathrm{C}$ and thicknesses of $0.5,1.0$ and $1.5 \mathrm{~cm}$, coefficients of determination $\left(\mathrm{R}^{2}\right)$, mean square deviations (MSD) and residual distribution (RD). All models led to good fits to the data, especially Midilli et al. (2002), which showed $\mathrm{R}^{2}>0.98$,
MSD $<0.015$ and random RD. A good model is considered as acceptable if the residual distribution is random (Goneli et al., 2011). Furtado et al. (2010), evaluating 'ceriguela' (Spondia purpurea L.) pulp foam-mat drying at temperatures of 60 , 70 and $80{ }^{\circ} \mathrm{C}$, observed that the Midilli et al. (2002) model showed the best fit to the data, since it had highest $\mathrm{R}^{2}$ and lowest estimated mean error (SE). The parameter $k$ (constant of drying rate) of the Midilli et al. (2002) model, for thickness of $0.5 \mathrm{~cm}$, increased with the increment in temperature up to

Table 4. Parameters, coefficients of determination $\left(R^{2}\right)$, mean square deviations (MSD) and residual distribution (RD) of the models fitted to F1 drying curves for thicknesses of $0.5,1.0$ and $1.5 \mathrm{~cm}$, at different temperatures

\begin{tabular}{|c|c|c|c|c|c|c|c|c|}
\hline \multirow{2}{*}{ Model/Thickness } & \multirow{2}{*}{$\begin{array}{c}\text { Temperature } \\
\left({ }^{\circ} \mathrm{C}\right)\end{array}$} & \multicolumn{4}{|c|}{ Parameter } & \multirow[b]{2}{*}{$\mathbf{R}^{2}$} & \multirow[b]{2}{*}{ MSD } & \multirow{2}{*}{ RD } \\
\hline & & \multicolumn{2}{|c|}{$K$} & & & & & \\
\hline \multirow{5}{*}{ Page $(0.5 \mathrm{~cm})$} & 50 & & & \multicolumn{2}{|c|}{1.3260} & 0.9964 & 0.0312 & $\mathrm{R}$ \\
\hline & 60 & & & \multicolumn{2}{|c|}{1.4276} & 0.9971 & 0.0185 & $\mathrm{R}$ \\
\hline & 70 & & & \multicolumn{2}{|c|}{1.4639} & 0.9991 & 0.0098 & B \\
\hline & 80 & & & \multicolumn{2}{|c|}{1.4910} & 0.9975 & 0.0168 & $\mathrm{R}$ \\
\hline & 90 & & & \multicolumn{2}{|c|}{1.6641} & 0.9961 & 0.0215 & $\mathrm{R}$ \\
\hline & & \multicolumn{2}{|c|}{ A } & \multicolumn{2}{|r|}{$\bar{C}$} & & & \\
\hline \multirow{5}{*}{ Exponential $(0.5 \mathrm{~cm})$} & 50 & 1.1686 & & & -0.1323 & 0.9921 & 0.0001 & B \\
\hline & 60 & 1.2137 & & & -0.1616 & 0.9899 & 0.0351 & $\mathrm{R}$ \\
\hline & 70 & 1.2902 & & & -0.2287 & 0.9917 & 0.0303 & B \\
\hline & 80 & 1.2742 & & & -0.2151 & 0.9888 & 0.0358 & B \\
\hline & 90 & 1.5233 & & & -0.4701 & 0.9872 & 0.0390 & $\mathrm{R}$ \\
\hline & & $\bar{A}$ & $\bar{K}$ & $n$ & $\bar{B}$ & & & \\
\hline & 50 & 0.9750 & 0.0017 & 1.3777 & -0.00006 & 0.9978 & 0.0127 & B \\
\hline & 60 & 0.9794 & 0.0020 & 1.4596 & -0.0001 & 0.9983 & 0.0143 & $\mathrm{R}$ \\
\hline IVIIIIIII et al. (2002) & 70 & 0.9957 & 0.0023 & 1.4387 & -0.0001 & 0.9996 & 0.0058 & B \\
\hline & 80 & 0.9854 & 0.0037 & 1.4891 & -0.0002 & 0.9985 & 0.0131 & $\mathrm{R}$ \\
\hline & 90 & 0.9766 & 0.0021 & 1.6610 & -0.0004 & 0.9982 & 0.0145 & B \\
\hline & & & & & & & & \\
\hline & 50 & & & & & 0.9984 & 0.0141 & B \\
\hline & 60 & & & & & 0.9992 & 0.0102 & $\mathrm{R}$ \\
\hline Page $(1.0 \mathrm{~cm})$ & 70 & & & & & 0.9995 & 0.0072 & $\mathrm{R}$ \\
\hline & 80 & & & & & 0.9982 & 0.0140 & B \\
\hline & 90 & & & & & 0.9975 & 0.0174 & $\mathrm{R}$ \\
\hline & & $\bar{A}$ & & & $\bar{C}$ & & & \\
\hline & 50 & 1.1576 & & & -0.1120 & 0.9954 & 0.0246 & B \\
\hline & 60 & 1.1587 & & & -0.1109 & 0.9947 & 0.0270 & B \\
\hline Exponential $(1.0 \mathrm{~cm})$ & 70 & 1.2509 & & & -0.2041 & 0.9953 & 0.0227 & B \\
\hline & 80 & 1.3377 & & & -0.2958 & 0.993 & 0.0265 & B \\
\hline & 90 & 1.3314 & & & -0.2555 & 0.9792 & 0.051 & B \\
\hline & & $\bar{A}$ & $\mathrm{~K}$ & $n$ & $\bar{B}$ & & & \\
\hline & 50 & 1.0059 & 0.0013 & 1.2531 & -0.00001 & 0.9987 & 0.0131 & B \\
\hline & 60 & 0.9954 & 0.0012 & 1.3233 & -0.00001 & 0.9996 & 0.0074 & $\mathrm{R}$ \\
\hline IVIIIIIII et al. (ZOUZ) & 70 & 0.9993 & 0.0013 & 1.3229 & -0.00001 & 0.9998 & 0.0035 & $\mathrm{R}$ \\
\hline & 80 & 0.9930 & 0.0011 & 1.3821 & -0.00011 & 0.9993 & 0.0087 & B \\
\hline & 90 & 0.9882 & 0.0005 & 1.6392 & -0.00000 & 0.9984 & 0.0142 & $\mathrm{R}$ \\
\hline & & & & & & & & \\
\hline & 50 & & & & & 0.9958 & 0.0237 & $\mathrm{R}$ \\
\hline & 60 & & & & & 0.9993 & 0.0244 & $\mathrm{R}$ \\
\hline Page (1.5 cm) & 70 & & & & & 0.9976 & 0.0174 & B \\
\hline & 80 & & & & & 0.9985 & 0.0133 & B \\
\hline & 90 & & & & & 0.9986 & 0.0136 & B \\
\hline & & $\bar{A}$ & & & C & & & \\
\hline & 50 & 1.2476 & & & -0.2288 & 0.9977 & 0.0172 & B \\
\hline & 60 & 1.1683 & & & -0.1203 & 0.9939 & 0.0001 & B \\
\hline Exponential $(1.5 \mathrm{~cm})$ & 70 & 1.2425 & & & -0.2081 & 0.9953 & 0.0245 & B \\
\hline & 80 & 1.2710 & & & -0.2231 & 0.9938 & 0.0278 & B \\
\hline & 90 & 1.2322 & & & -0.1886 & 0.9964 & 0.0220 & B \\
\hline & & $\bar{A}$ & $\bar{K}$ & $\bar{N}$ & $\bar{B}$ & & & \\
\hline & 50 & 1.0000 & 0.0013 & 1.1474 & -0.0001 & 0.9984 & 0.0145 & $\mathrm{R}$ \\
\hline & 60 & 0.9954 & 0.0010 & 1.3354 & -0.0001 & 0.9992 & 0.0106 & $\mathrm{R}$ \\
\hline Midilli et al. (2002) & 70 & 0.9890 & 0.0011 & 1.3212 & -0.0001 & 0.9991 & 0.0107 & B \\
\hline$(1.5 \mathrm{~cm})$ & 80 & 0.9972 & 0.0011 & 1.3555 & -0.0001 & 0.9993 & 0.0091 & B \\
\hline & 90 & 0.9981 & 0.0018 & 1.3047 & -0.0001 & 0.9996 & 0.0073 & $\mathrm{R}$ \\
\hline
\end{tabular}

R - Random; B - Biased. F1 - pulp $+1.5 \%$ Emustab $^{\circledast}+0.5 \%$ Super Liga Neutra ${ }^{\circledR}$ 
$80^{\circ} \mathrm{C}$. This parameter represents the effect of external drying conditions and tend to increase with the elevation of drying air temperature (Goneli et al., 2009). The higher the value of this parameter, the faster the drying process. The parameter $n$ of the Midilli et al. (2002) and Page models, which is related to the internal resistance of the material to drying (Perez et al., 2013), increased with the increment of temperature. Similar behavior was observed by Madureira et al. (2011), fitting the drying data of the formulation with cactus pear pulp mixed with $25 \%$ modified starch.

Figure 2 shows the drying kinetics of F1 for thicknesses of $0.5,1.0$ and $1.5 \mathrm{~cm}$ at different temperatures $(50,60,70,80$ and $90{ }^{\circ} \mathrm{C}$ ) fitted to the Midilli et al. (2002) model, the best one among the models tested. Furtado et al. (2014), in 'Pérola' pineapple foam-mat drying at temperatures of 60,70 and 80
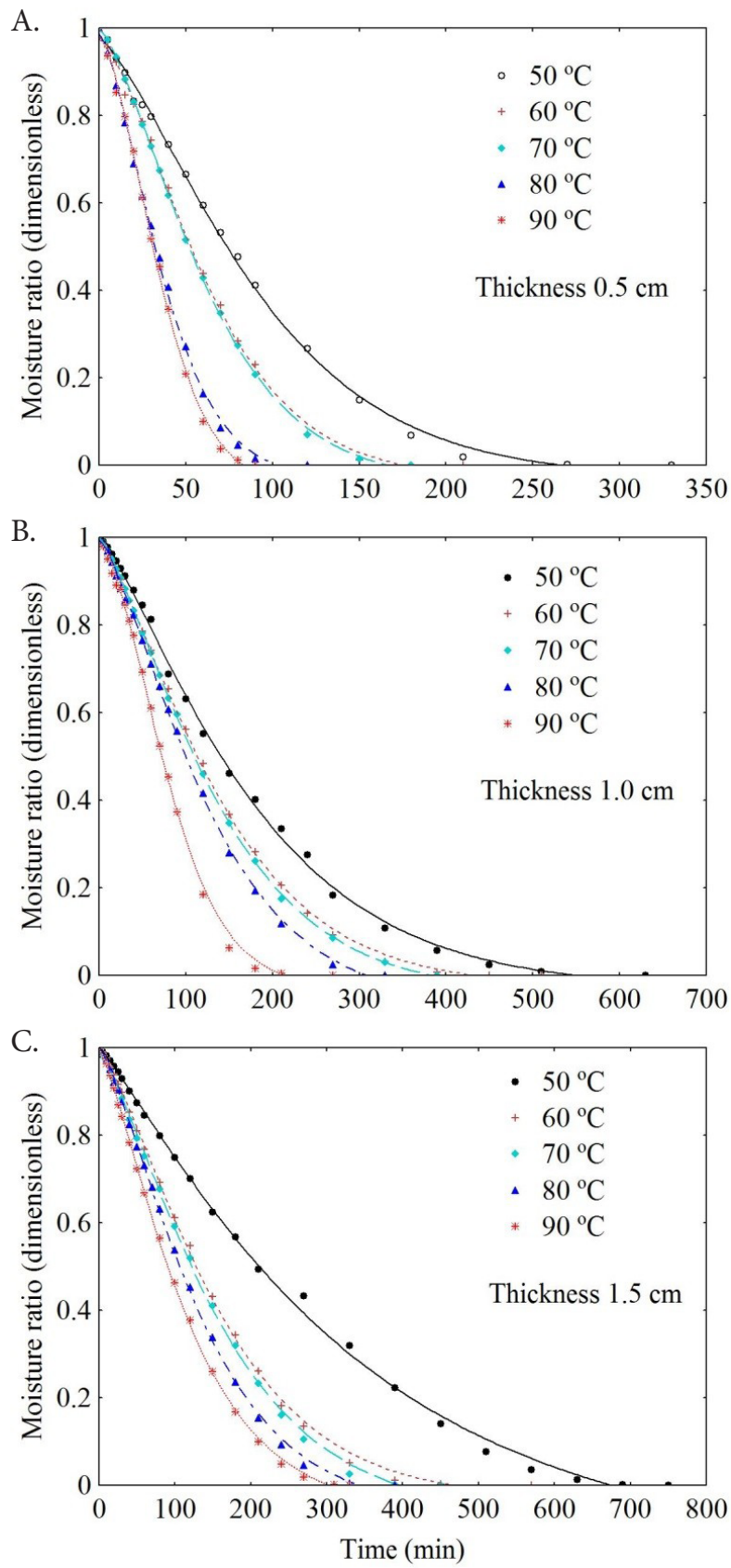

Figure 2. Drying kinetics of Formulation F1 (F1 - pulp $+1.5 \%$ Emustab $^{\circledR}+0.5 \%$ Super Liga Neutra ${ }^{\circledR}$ ) with thicknesses of $0.5,1.0$ and $1.5 \mathrm{~cm}$ at different temperatures fitted by the Midilli et al. (2002) model
${ }^{\circ} \mathrm{C}$, observed that the Midilli et al. (2002) model showed the highest $\mathrm{R}^{2}$ and lowest SE.

The curves were influenced by temperature, with gradual reduction of the times when higher temperatures of the drying air were used, for all thicknesses. The influence of the increase of temperature on drying time is expected and reported by Kadam \& Balasubramanian (2011) in tomato foam-mat drying. For all temperatures and thicknesses, the drying curves exhibit higher water loss in the beginning of the drying process. Rajkumar et al. (2007) also noted that mango pulp foam exhibited higher drying rate in the beginning than in the end, justifying that the water movement rate from the inner to the outer surface decreases in the final drying phase and, consequently, lower drying rates occur.

The drying process was, in all samples, faster for smaller thicknesses, demonstrating that thickness has significant impact on foam drying. Raharitsifa \& Ratti (2010), evaluating the drying of apple foam with thicknesses of 1,4 and $6 \mathrm{~cm}$, observed that the smaller the thickness, the shorter the drying time.

\section{Conclusions}

1. Incorporation of $1.5 \%$ Emustab $^{\circledR}$ and $0.5 \%$ Super Liga Neutra ${ }^{\circledR}$ to the myrtle pulp (Formulation F1) proved to be effective, with the best characteristics for the drying.

2. Addition of additives influenced the physical-chemical parameters of myrtle pulp.

3. The Midilli et al. (2002) model showed the best fits to the experimental data.

\section{Literature Cited}

AOAC - Association of Official Analytical Chemists. Official Methods of Analysis. 15.ed. Arlington: AOAC, 2007. 1279p.

Barreto, I. M. A. Caracterização de polpa de pitanga roxa (Eugenia uniflora) desidratada em leito de espuma. Itapetinga: UESB, 2011. 63p.

Chaves, A. M.; Barreto, I. M. A.; Reis, R. C.; Kadam, D. M. Physicochemical and sensory properties of purple Brazilian cherry (Eugenia uniflora, L.) foams. International Journal of Food Science and Technology, v.48, p.1688-1697, 2013. https://doi.org/10.1111/ijfs.12139

Falade, K. O.; Adeyanju K. I.; Uzo-Peters, P. I. Foam-mat drying of cowpea (Vigna unguiculata) using glyceryl monostearate and egg albumin as foaming agents. European Food Research Technology, v.217, p.486-491, 2003. https://doi.org/10.1007/s00217-003-0775-3

Feitosa, R. M.; Figueirêdo, R. M. F. de; Queiroz, A. J. de M.; Silva, R. M.; Silva, R. C.; Oliveira, E. N. A. Influência de adjuvante de secagem em diferentes proporções na polpa da murta. João Pessoa: Instituto Bioeducação, 2016. p.1005-1008.

Francis, F. J. Analysis of anthocyanins. In: Markakis, P. Anthocyanins as food colors. Cap. 7. New York: Academic Press, 1982. p.181-207. https://doi.org/10.1016/B978-0-12-472550-8.50011-1

Furtado, G. de F.; Silva, F. S. da; Porto, A. G.; Santos, P. dos. Secagem de polpa de ceriguela pelo método de camada de espuma. Revista Brasileira de Produtos Agroindustriais, v.12, p.9-14, 2010. https:// doi.org/10.15871/1517-8595/rbpa.v12n1p9-14

Furtado, G. de F.; Silva, F. S. da; Porto, A. G.; Santos, P. dos. Secagem de abacaxi (Ananas comosus (L.) Merril), variedade pérola utilizando a técnica de camada de espuma. Revista Brasileira de Produtos Agroindustriais, v.16, p.387-394, 2014. https://doi. org/10.15871/1517-8595/rbpa.v16n4p387-394 
Goneli, A. L. D.; Corrêa, P. C.; Afonso Júnior, P. C.; Oliveira, G. H. H. de. Cinética de secagem dos grãos de café descascados em camada delgada. Revista Brasileira de Armazenamento, v.11, p.64-73, 2009.

Goneli, A. L. D.; Corrêa, P. C.; Magalhães, F. E. de A.; Baptestini, F. M. Contração volumétrica e forma dos frutos de mamona durante a secagem. Acta Scientiarum. Agronomy, v. 33, p.1-8, 2011. https:// doi.org/10.4025/actasciagron.v33i1.4629

Kadam, D. M.; Balasubramanian, S. Foam mat drying of tomato juice. Journal of Food Processing and Preservation, v.35, p.488-495, 2011. https://doi.org/10.1111/j.1745-4549.2010.00492.x

Kadam, D. M.; Wilson, R. A.; Kaur, S.; Manisha. Influence of foam mat drying on quality of tomato powder. International Journal of Food Properties, v.15, p.211-220, 2012. https://doi. org/10.1080/10942911003763701

Karim, A. A.; Wai, C. C. Foam-mat drying of starfruit (Averrhoa carambola L.) purée: Stability and air drying characteristics. Food Chemistry, v.64, p. 337-343, 1999. https://doi.org/10.1016/ S0308-8146(98)00119-8

Madureira, I. A.; Figueirêdo, R. M. F. de; Queiroz, A. J. de M.; Silva Filho, E. D. da. Cinética de secagem da polpa do figo-da-india. Revista Brasileira de Produtos Agroindustriais, v.13, p.345-354, 2011. https://doi.org/10.15871/1517-8595/rbpa.v13n4p345-354

Midilli, A.; Kucuk, H.; Yapar, Z. A new model for single-layer drying. Drying Technology, v.20, n.7, p.1503-1513, 2002. http://dx.doi. org/10.1081/DRT-120005864

NREL - National Renewable Energy Labotory. Dilute acid hydrolysis procedure for determination of total sugars in the liquid fraction of process samples. Colorado: Golden, 2008. 11p.

Obón, J. M.; Castellar, M. R.; Alacid, M.; Fernández-López, J. A. Production of a red-purple food colorant from Opuntia stricta fruits by spray drying and its application in food model systems. Journal of Food Engineering, v.90, p.471-479, 2009. https://doi. org/10.1016/j.jfoodeng.2008.07.013

Oliveira, M. I. S.; Tonon; R. V.; Nogueira; R. I.; Cabral, L. M. C. Estabilidade da polpa de morango atomizada utilizando diferentes agentes carreadores. Brazilian Journal of Food Technology, v.16, p.310-318, 2013. https://doi.org/10.1590/S198167232013005000037

Perez, L. G.; Oliveira, F. M. N. de; Andrade, J. S.; Moreira Filho, M. Cinética de secagem da polpa cupuaçu (Theobroma grandiflorum) pré desidratada por imersão-impregnação. Revista Ciência Agronômica, v.44, p.102-106, 2013. https://doi. org/10.1590/S1806-66902013000100013

Raharitsifa, N.; Genovese, D. B.; Ratti, C. Characterization of apple juice foams for foam-mat drying prepared with egg white protein and methylcellulose. Journal of Food Science, v.71, p.141-151, 2006. https://doi.org/10.1111/j.1365-2621.2006.tb15627.x
Raharitsifa, N.; Ratti, C. Foam-mat freeze-drying of apple juice part 1: Experimental data and ann simulations. Journal of Food Process Engineering, v.33, p.268-283, 2010. https://doi. org/10.1111/j.1745-4530.2009.00400.x

Rajkumar, P.; Kailappan, R.; Viswanathan, R.; Raghavan, G. S. V. Drying characteristics of foamed alphonso mango pulp in a continuous type foam mat dryer. Journal of Food Engineering, v.79, p.1452-1459, 2007. https://doi.org/10.1016/j. jfoodeng.2006.04.027

Sangamithra, A.; Venkatachalam, S.; John, S. G.; Kuppuswamy, K. Foam mat drying of food materials: A review. Journal of Food Processing and Preservation, v.39, p.3165-3174, 2015. https:// doi.org/10.1111/jfpp.12421

Silva, F. de A. S. e; Azevedo, C. A. V. de. The Assistat Software Version 7.7 and its use in the analysis of experimental data. African Journal of Agricultural Research, v.11, p.3733-3740, 2016. https://doi. org/10.5897/AJAR2016.11522

Skrede, G.; Wrolstad, R. E.; Lea, P.; Enersen, G. Color stability of strawberry and blackcurrant syrups. Journal of Food Science, v.57, p.172-177, 1992. https://doi.org/10.1111/j.1365-2621.1992. tb05449.x

Soares, E. C. Caracterização de aditivos para secagem de araça-boi (Eugenia stipitata Mc Vaugh) em leito de espuma. Itapetinga: UESB. 2009. 88p. Dissertação Mestrado

Soares, E. C.; Oliveira, G. S. F. de; Maia, G. A.; Monteiro, J. C. S.; Silva Júnior, A.; Souza Filho, M. de S. M. de. Desidratação da polpa de acerola (Malpighia emarginata D. C.) pelo processo "foam-mat". Ciência e Tecnologia de Alimentos, v.21, p.164-170. 2001. https:// doi.org/10.1590/S0101-20612001000200008

Sousa, P. H. M. de; Maia, G. A.; Souza Filho, M. de S. M. de; Figueiredo, R. W. de; Souza, A. C. R. de. Goiabas desidratadas osmoticamente seguidas de secagem em estufa. Revista Brasileira de Fruticultura, v.25, p.414-416, 2003. https://doi.org/10.1590/ S0100-29452003000300013

Souza, V. C.; Barreto, I. M. A.; Souza, B. dos S.; Chaves, M. A. Utilização do Emustab $^{\circledR}$ na obtenção de espuma de polpa de cupuaçu (Theobroma grandiflorum) visando a desidratação por foam-mat drying. Higiene Alimentar, v.25, p.1403-1404, 2011.

Thuwapanichayanan, R.; Prachayawarakorn, S.; Soponronnarit, S. Effects of foaming agents and foam density on drying characteristics and textural property of banana foams. LWT Food Science and Technology, v.47, p.348-357, 2012. https://doi. org/10.1016/j.lwt.2012.01.030

Widyastutil, T. E. W.; Srianta, I. Development of functional drink based on foam-mat dried papaya (Carica papaya L.): Optimisation of foam-mat drying process and its formulation. International Journal of Food, Nutrition and Public Health, v.4, p.167-176, 2011. 